\title{
International Business Negotiations: Search of the Balance and the Equilibrium of Negotiating Powers, under Distorting Market Conditions of Competition (Monopsony, Oligopsony and Monopoly Cases)
}

\author{
Kęstutis Peleckis $^{1}$, Valentina Peleckienè ${ }^{2}$, Kęstutis Peleckis ${ }^{3}$ \\ ${ }^{1}$ Department of International Economics and Business Management, \\ ${ }^{2}$ Department of Social Economics and Management, \\ ${ }^{3}$ Department of Economics and Management of Enterprises, \\ Vilnius Gediminas Technical University, Vilnius, Lithuania \\ E-mails: ${ }^{1}$ k.peleckis@vgtu.lt (corresponding author); ${ }^{2} v$.peleckiene@vgtu.lt; \\ ${ }^{3}$ kestutis.peleckis@vgtu.lt \\ Received 02 February 2017; accepted 12 April 2017
}

\begin{abstract}
Certain challenges arise in business negotiations when competition in the market is more or less distorted. This can take place in various markets conditions. In such situations great possibilities open up to the development of international business relations as overclocking new market participants can provide additional alternatives for companies and organizations or other business units, by reducing the negative impact of competition distortions for the balance of negotiating power of participants in negotiations. In the development and implementation of effective international business negotiation strategy, it is important to identify the balance of negotiating power of major participants in negotiations in order to make more efficient use of the potential of business negotiations - the negotiating powers. The aim of this article is to analyze in complex the unfolding theory and practice of development and implementation of international business negotiations and negotiating strategies under distorting market competition conditions, to reveal opportunities on development and implementing improvements of these strategies in cases of monopsony, oligopsony and monopoly. Object of the research is the search of balance on negotiating powers in international business negotiations under conditions of distorted competition in the market. The scientific problem - negotiation theory lacks measures for assessment and balancing the negotiating powers of negotiation's participants under distorted market competition.
\end{abstract}

Keywords: negotiation, negotiation strategy, negotiation power, the balance of negotiating powers, distortion of competition, international business.

JEL Classification: F51, M16.

Conference topic: Internationalization Processes: Contemporary Challenges.

\section{Introduction}

New challenges arise for business negotiations because of conditions, which are distorting the market competition. This affects on the balance of negotiating powers of participants in negotiations. Such situations often result in negative consequences for both buyers and sellers. As a result, it opens additional opportunities for international business because of the emergence of other market participants in the relevant markets, which can provide additional alternatives for both buyers and sellers by reducing the negative impact on the distortion of competition, balancing the negotiating powers of negotiating sides (Kiryluk-Dryjska 2016; Brett, Thompson 2016; Przybyła-Kasperek, Wakulicz-Deja 2016; Schaerer et al. 2016; Ghavami et al. 2016; Rufo et al. 2016; Jäger et al. 2017). In the development and implementation of effective international business negotiation strategy the assessment of situation on negotiating powers of negotiating parties and essential components of their deviation from equilibrium is important in order to make effective use of the potential of business negotiations - the negotiating powers. When deciding scientific problem it is necessary to ensure the use of such solutions which would take into consideration the balance of negotiating power of participants in the negotiations, allowing them to balance and to ensure that the creation and implementation of negotiation strategy should be maximally effective.

(C) 2017 K. Peleckis, V. Peleckienè, K. Peleckis. Published by VGTU Press. This is an open-access article distributed under the terms of the Creative Commons Attribution (CC BY 4.0) License, which permits unrestricted use, distribution, and reproduction in any medium, provided the original author and source are credited. 

negotiating powers, under distorting market conditions of competition (monopsony, oligopsony and monopoly cases)

The higher number of sellers, suppliers, allows the buyer to have a greater variety of solutions, more alternatives. In this case, the buyer can take advantage of competitive tension situation in their own favor. However, it is different situation under the absence of competitive pressures in the market. One of the reasons resulting in a lack of competitive pressures in the market is that the number of suppliers is not sufficient to create a free and open competition, for example, the monopoly case. Therefore, we can define the distortion of market as the absence of free and open competition. Free competition means that market participants are competing with each other, instead of cooperating with each other, by creating and maintaining the cartel. Open competition means that the market entry barriers are sufficiently low, in this case profits of existing players are not too large because otherwise new entrants would come, who would try to sell with lower profits, which would in fact be useful for customers, and thus would ensure their sales.

There are two powers of buyer: the power, arising from nature of the market (monopsonistic, oligopolistic and monopolistic markets cases), and negotiating power. The buyer has the monopsonistic power if he can reduce the price so that it would be significant. Negotiating power depends on the bargaining strength which the buyer can demonstrate by communicating and negotiating with suppliers. The buyer can easily get a lower price from monopsonistic power than using the negotiating powers. The negotiating power is used only when the supplier has a corresponding market power and with the help of the negotiating power seeks to offset it. The consequences of the use of each type of buyer power are very different. In case of monopsonistic and oligopolistic markets the power of buyers decreases the volume of sales and productivity in supply market - which ultimately negatively affects the consumer market. The negotiating power which has buyers is more of a compensatory nature. It increases the volume of production in suppliers market and can improve the market situation in the consumer market.

Object of the scientific article - is search of the balance on negotiating powers in international business negotiations under conditions of distorted competition in the market.

The aim of the research - is to analyze in complex the unfolding theory and practice of development and implementation of international business negotiations and negotiating strategies under distorting market competition conditions, to reveal opportunities on development and implementing improvements of these strategies in cases of monopsony, oligopsony and monopoly.

The scientific problem - negotiation theory lacks measures for assessment and balancing the negotiating powers of participants in negotiations under distorted market competition.

\section{The relevance of the study and problem investigation level}

The relevance of work has both theoretical and practical aspects. The theoretical relevance is related to the assessment and development of the negotiating power of participants in international business negotiations and scientific search of measures to ensure their effectiveness and the creation of science-based, sustainable and effective negotiation power balancing system, enabling to act effectively for negotiating team in distorted market competition. The practical relevance is associated with challenges of the business organization, increasing purposefulness of recent developments, which unfolds more and more alternative business solutions, the need to search the new business partners, leading to greater efficiency of business transactions, their efficiency and ultimately increasing the competitiveness of businesses in international business. Thus theoretical and practical relevance of this research can be characterized by the need to find and scientifically justify measures to balance negotiating powers of business negotiations participants. They should help to assess objectively negotiating powers and their relationships between participants of international business negotiations and their competitors, to form and use purposefully and effectively the negotiating powers of negotiating team. These measures should guarantee the development and implementation of effective business negotiation strategy, international business development and competitiveness in the context of taking into account the conditions of competition in the market-distorting circumstances.

In scientific literature, implementation of effective business negotiation strategies was dealt by the following authors: Moosmayer et al. (2013); Wilken et al. (2013); Khakhar, Rammal (2013); Przybyła-Kasperek, WakuliczDeja (2016); Peleckis et al. (2016); Schaerer et al. (2016); Dinkevych et al. (2016); Dunne et al. (2016); Ghavami et al. (2016); Weiss (2017).

The importance of searching the alternatives for strengthening the negotiating power underlined a number of scientists: Antaki, Kent (2015); Petriwskyj et al. (2015); Alavoine, Estieu (2015); Kiryluk-Dryjska (2016); Brett, Thompson (2016); Przybyła-Kasperek, Wakulicz-Deja (2016); Schaerer et al. (2016); Ghavami et al. (2016); Rufo et al. (2016); Peleckis (2016); Jäger et al. (2017).

The distortion of market competition conditions and circumstances, examined the following scientists: monopsony cases - Dassiou and Glycopantis (2008); OECD (2008); Matsudaira (2014); Danziger (2010); Bonanno and Lopez (2012); Barr and Roy (2008); Brennan (2011); Melnikas and Smaliukienè (2007); Strobl and Walsh (2007); monopoly cases - Mirman et al. (2014); Rogers 2013; Braido and Shalders (2015); Sarafopoulos (2015); Jablanovic (2013); Willington and Ning (2014); Mumuni et al. (2016); Lai et al. (2016); Mendoza (2016); Matsumoto and Szidarovszky (2015); Kováč and Žigić (2016); Shin (2017). 
Peleckis, K.; Peleckiene, V.; Peleckis, K. 2017. International business negotiations: search of the balance and the equilibrium of negotiating powers, under distorting market conditions of competition (monopsony, oligopsony and monopoly cases)

\section{Monopsony and power of buyer}

Monopsonistic power is a mirror reflection of monopoly power: it is a buyer's market power but not seller's market power (Dassiou, Glycopantis 2008; Matsudaira 2014; Danziger 2010; OECD 2008; Bonanno, Lopez 2012; Barr, Roy 2008; Brennan 2011; Strobl, Walsh 2007). Monopsonistic power can be invoked directly and indirectly. Directly it is determined in cases when is compared competitive market price with the buyer's price obtained. While in the market is known prevailing price level of competing companies, but it does not reflect the actual purchase price. Indirect monopsonistic power evaluation method includes factors such as the market, market share, barriers of entrance and other relevant factors.

The power of buyers is related to the way in which the purchasing companies may affect the trading relationships with sellers and suppliers. The power of buyer can occur through monopsonistic power and through the buyer's negotiating powers. The difference between these two powers of buyers is based on the structure of their sources and the totality of the measure's effect.

Business entity is considered having a monopsonistic power when its purchases part in the market is relatively high and it can affect the price depending on sales volumes. Differences in the use of negotiating power are reflected in the level of discounts obtained. The negotiating power of the buyer indicates the bargaining strength in relation with the supplier. The use of both types of buyer's power promotes a move to the level of lower sales prices. In the case of monopsonistic power this is achieved through the emphasis on lower purchase volumes, when during the actions of negotiating power is promised to buy less (Brennan 2011; Strobl, Walsh 2007). The main difference, which is revealed in the case of monopsonistic power is that in this case the prices are reduced below competitive level, when in the case of negotiating power seller operates still in a competitive level (OECD 2008; Bonanno, Lopez 2012; Strobl, Walsh 2007). Monopsonistic and oligopsonic power (assuming that there is no price discrimination) leads to market distortions. It is, as a rule, is detrimental to both direct sellers, suppliers as well as further members of the supply chain (Matsudaira 2014; Danziger 2010; OECD 2008).

Monopsonistic power supply in the market determines the profit transfer from supplier to buyer. Business entity with monopsonistic market power behaves in a market so as if he had the higher marginal costs, compared with a company that does not have monopsonistic power. Because of this ultimately increase the price to the end user, even if the costs are lower. If monopsonist still has market power in the supply market, he does even more damage than if it should not have.

Customers using negotiating power as a compensatory element (for example, where negotiating power completely or partially compensates market power of sellers), it may increase the volume of production in the market and increase the welfare of final consumers in the market. The extent to which customers receive the benefits from negotiating power depends on the nature of contracts with suppliers and the level of consumer market competitiveness. Increased consumer competition and their extent determine that this negotiating power provides higher discounts for wholesale price, and brings greater benefits to consumers (OECD 2008; Bonanno, Lopez 2012; Strobl, Walsh 2007).

In examination of monopsonistic power in practice is noted that it is determined by the available alternatives of sellers, which determines certainty of the buyer's monopsonistic power. If sellers can easily find other buyers, then the buyer will have a limited monopsonistic power. Other sellers can be in different geographical regions and may vary in their activity, may differ in their needs in the market, but the products can satisfy the same needs. Also in searching for new markets are important to identify the monopsonistic power of presence in smaller geographic areas, with a smaller number of products where a hypothetical monopsonist in that territory could affect the price drop (Antaki, Kent 2015; Petriwskyj et al. 2015; Alavoine, Estieu 2015; Przybyła-Kasperek, Wakulicz-Deja 2016; Schaerer et al. 2016; Ghavami et al. 2016; Rufo et al. 2016; Jäger et al. 2017).

When amount of buyers and sellers is small, the negotiations may take place due to the possible excess profit between buyer and seller according to their capabilities. Allocation of excess profits depends on the relative negotiating power. This surplus profit is the objective of buyers and seller' goal that motivates them to agree and do not look to other alternatives. The more efficient is the buyer's negotiating, the more he has alternatives, but if seller has less alternatives thus, the buyer will receive more surplus profit share. The profit of buyers transaction depends on his ability and willingness to look for alternative suppliers. Similarly, the profit of seller transaction depends on his ability and willingness to look for other buyers. The essential factors influencing negotiating power, which shows that the buyer has more alternatives than the seller: the buyer can easily switch suppliers without incurring significant additional costs (the buyer is intermediary of a consumer market) (Matsudaira 2014; Danziger 2010; OECD 2008; Bonanno, Lopez 2012; Brennan 2011; Strobl, Walsh 2007).

\section{Monopsonistic power}

The current supplier's model has influence to activity of monopsonistic power. Suppliers market models can be divided into Ricardo, quasi or monopoly models (Matsudaira 2014; Danziger 2010; OECD 2008; Bonanno, Lopez 2012; Strobl, Walsh 2007; Barr, Roy 2008; Brennan 2011):

1. Ricardo model exists when the supply of raw materials which is used by supplier, is different. In this case, monopsonistic power depends on the elasticity of supply. The more elastic supply, the greater opportunity is to use the monopsonistic power, which determines the output disruptions of supply market and damaging the end users. 
Company with monopsonistic power in supply market will behave in such a way as if would have more consumption than a company that does not have a monopsonistic power. If monopsonist has a power in supply market thus the damage occurs both for productivity of suppliers and consumers. Having monopsonistic power it is necessary to recognize whether the seller has an alternative, which determines the monopsonistic power. If the seller can easily find other buyers in the local market or in another geographical area, or customers who will use the products as a substitute, then the buyer has the limited monopsonistic power.

2. Quasi model is the difference between total revenues and short term expenditures. In short term monopsonist can take advantage. In the long term, any attempt to use suppliers situation may encourage them not to conclude a deal: the suppliers would not regain their investment. If in suppliers market prevails fair competition, monopsonist will not be able to use monopsonistic power over the long term.

3. In monopoly case model supplier and the buyer are more oriented towards maximizing the total profit than willing to refuse to cooperate. The creation of compensatory power in case of monopoly model may lead to reductions in the prices for end users. However, such a case could lead to the collapse of deal, if one of the participants will withdraw. This will encourage the buyer to look for other markets.

\section{Occurring monopsony cases}

Oligopsony among buyers. If there is oligopsonic situation between the buyers and the supply is high, then frequently Nash equilibrium stabilizes. When there is Nash equilibrium procurement, each buyer shall establish its product value with regard to determined values of all buyers. In the case of Nash equilibrium will be exploited the market power of buyers, which will depend on the product threshold value, the number of competing buyers, supply elasticity (Dassiou, Glycopantis 2008; Matsudaira 2014; Danziger 2010).

Cartel monopsonists. Oligopsonic Nash equilibrium does not maximize customer profits. Therefore, there is a need to coordinate the purchases by exploiting the collective power of market, by increasing profits, reducing purchases and selling prices (OECD 2008; Bonanno, Lopez 2012).

Refusal of the transaction. Monopsonists can threaten to renounce the agreement thus demanding more beneficial conditions. For example, it is proposed to purchase a greater quantity of goods, but at a price that corresponds to a significantly smaller amount. The suppliers in this case cover only their production costs. However they ensure only its capacity utilization (Strobl, Walsh 2007; Barr, Roy 2008; Brennan 2011).

We reviewed some aspects of distorted market competition in cases of monopsony and oligopsony. Also we set out measures to reduce or eliminate negative effects of monopsony and oligopsony by taking advantages of opportunities in international business negotiations. Next, it is appropriate to examine the monopolistic power of suppliers, possibilities for its determination and evaluation and to provide the means to direct the power.

\section{Monopoly and power of the supplier}

Frequently in purchasing procedures, of business entities are states that in procurement should be invited to submit proposals at least three participants. This assumption means that higher number of suppliers allows to obtain a greater variety of solutions. In this case, the buyer uses the competitive tension situation in their favor. However, it is otherwise, if in the market does not exist a competitive tension. One of the reasons for the lack of competitive pressures in the market, is that the number of suppliers is not sufficient to create a free and open competition, such as in the case of monopoly. Therefore, market distortion can be called as situations, where there is no free and open competition. Free competition means that the available market participants are competing with each other rather than cooperating with one another by creating and maintaining the cartel. Open competition means that the market entry barriers are sufficiently low. In this case, the profits of market participants are not too large, otherwise would come new participants that would try to sell with lower profits, which would in fact be useful to customers, and thus to ensure its sales (Mumuni et al. 2016; Lai et al. 2016; Shin 2017).

Next we will review the causes of these distortions of the market - the market structure, market concentration, competition.

\section{Market structure}

What is the number of market participants, which ensure a fair and open competition? Frequently in business entities procurement rules are referred to the number " 3 ". But three suppliers do not always guarantee competition. Monopoly is characterized by a situation where is the sole supplier in the market, but there are other reasons for which the buyer may be faced with a de facto monopoly situations (Rogers 2013; Mendoza 2016; Matsumoto, Szidarovszky 2015; Kováč, Žigić 2016; Shin 2017):

- restrictions of patent or intellectual property, which limit the ability of other suppliers to offer the same or a similar solution;

- the end user wants a particular supplier (with agents), thus limiting the freedom of choice;

- other solutions in the market are technically not acceptable for business; 
Peleckis, K.; Peleckiene, V.; Peleckis, K. 2017. International business negotiations: search of the balance and the equilibrium of negotiating powers, under distorting market conditions of competition (monopsony, oligopsony and monopoly cases)

- costs of the supplier change are so high that it is impossible to change the supplier, as there will not be pay back of the costs incurred, so they are obliged to remain with the same supplier;

- company policy can prevent the purchase from specific countries or to compell to buy from a particular supplier on the reciprocial trade agreement.

\section{Market concentration}

The fact that in the market there are only three suppliers, can hide the fact that two suppliers can have shared the market. These suppliers may have such power that they can determine the prices. The amount of suppliers in the market is not always the best reflection of the level on participant's competition. Therefore, the market structure should be analyzed and deeper inspected by examining four or more market participants. When a small number of companies dominate in the market, it is called an oligopoly. Oligopoly can describe the four-firm concentration ratio, if the market top four-firm concentration ratio is above 40 percent - then the market is considered oligopolistic (Matsumoto, Szidarovszky 2015; Rogers 2013; Kováč, Žigić 2016; Shin 2017).

\section{Competition level}

Besides the number of suppliers in the market and the market structure there are important conditions under which suppliers compete with each other. And this is more difficult to be measured, neither the number of participants in the market or the market structure. The participants can take part in the buyer's established rules and can compete within the limits for which several suppliers mutually agreed, what are the benefits to the suppliers' interests (Lai et al. 2016; Mendoza 2016; Shin 2017). Although the activity against the reduction of competition is illegal, but it that does not mean that cartel doesn't exist. The benefits of such agreements can often be much higher neither constituting threat of a fine, thus detection and proof of cartel is really a complicated thing.

\section{Symptoms on the cartel behavior}

There are three types of cartel (Rogers 2013; Lai et al. 2016; Mendoza 2016; Matsumoto, Szidarovszky 2015):

- fixed price cartel;

- market sharing cartel;

- cartel of secret bidders agreement.

As an alternative to a fixed price cartel can be shared territory, where suppliers agree not to make proposals in the territory to another supplier. Therefore, the relevant supplier can raise prices by knowing that competitors will not make offers (Mumuni et al. 2016; Shin 2017). Or cartel can be organized even simpler - by agreeing not to sell to a particular customers or to a particular client in a given area. Market sharing arrangements can take several forms. Suppliers may jointly decide how many competitions can win each of them. Accordingly, all suppliers are taking part in competitions, but it is known in advance which from the suppliers will sign a contract. Market sharing often occurs there dominated by a few suppliers when buyers are fragmented and uncoordinated (Lai et al. 2016; Mendoza 2016; Matsumoto, Szidarovszky 2015).

In such cases is not easy to prove that anti-competitive behavior is determined by geography, logistics or other market characteristics. In the market can be arranged agreements on price caps or discount level. This simplifies the predictable buyers, which helps more to manipulate on proposals. It is available to give some examples:

- one or more participants may refuse to submit such proposals, that a competitor would win;

- suppliers provide not competitive offers or consciously such proposals that do not comply with the conditions;

- suppliers offer proposals, but agreed rotation is going for the best price, depending on who should win the contract.

For example, the winner of competition chanes every two years, even though the competitive advantages of participants remain unchanged.

\section{Other sources of market distortion}

To make a deal is easier than termination. In the market may be companies that are trying to get rid of unprofitable customers and further exploit the profitable customers. Although the supplier increases the prices, it can't be changed, because the replacement cost will be higher neither possible benefits of cooperation with another supplier. Therefore, the existing supplier continues to exploit buyer carrying him a big profit (Braido, Shalders 2015). Market can be or not to be distorted, but suppliers may still seek to exploit customers. Next are presented possible questions, the answers to which may indicate whether the client is being exploited (Matsumoto, Szidarovszky 2015; Kováč, Žigić 2016; Rogers 2013):

-Does the annual expenditures rise disproportionately in comparison with the need or cost?

-Does the level of the supplier's price grow more neither due the influence of inflation is growing the price level?

-Does the services of the supplier are of better quality, in respect of which prices are growing? 
Peleckis, K.; Peleckiene, V.; Peleckis, K. 2017. International business negotiations: search of the balance and the equilibrium of negotiating powers, under distorting market conditions of competition (monopsony, oligopsony and monopoly cases)

- Are the requirements and / or additional charges are higher than those of other suppliers in the same sector?

- Does the company's bookkeeping assess the impact of the provided supplier's services for the company's profitability?

- Is there evidence that the supplier's representatives are trying to influence our company's personnel decisions?

-Does the supplier is trying to restrict us to terms of the contract, specifications which will limit us respectively to receiving services?

- Does the supplier behave properly in negotiations, do not give discounts and seek to maximize profits?

These questions and answers to them enable better to understand whether the suppliers exploit customers in their favor.

\section{Global sources of distortion}

The purchasing procedures usually provide the requirement for competitive bidding and often require three proposals. If there are 10 potential suppliers of the relevant category and are invited only three of them to submit proposals, so there are only 30 percent of probability to find the best supplier. It is impossible to find procurement rules that need to get 10 proposals, while purchasing professionals and will not invite only 3 suppliers random, so it is necessary to study carefully the market before, and to consider the possible suppliers of unexplored markets. Even if the market is monopolistic, it may be that new entrants came will come to it. In order to find suitable suppliers it is necessary to assess the following sources for search of potential suppliers (Rogers 2013; Mumuni et al. 2016; Lai et al. 2016; Shin 2017):

- catalogues of global coverage of a specific category of online supply goods;

- to consult with specialists of specific goods supply category;

- to communicate with suppliers of other countries of the same professional category;

- exhibitions and presentations in other countries;

- the agencies or consultants for market cooperation;

- to recruit a mediator to help finding cheaper suppliers in other countries.

Looking for new suppliers can help to expand the available alternatives, thus increasing their negotiating power as a buyer. Also attaining to have more alternatives, it is necessary to expand the existing market boundaries (Antaki, Kent 2015; Alavoine, Estieu 2015; Kiryluk-Dryjska 2016; Brett, Thompson 2016). This can be done by examining similar or related markets, which can become a potential supplier's market. Sometimes, for other market participants are quite difficult to switch to work in another market. Therefore, looking for a potential cheaper partner in other markets can provide early warning of potential negotiating proposals, which would facilitate future potential partner of determination to work together in a new market (Rogers 2013; Shin 2017):

- sharing of experiences, such as the posting of project managers, or transmission of technology through joint meetings;

- to subsidize certain costs of entry, or to buy the appropriate measures, or otherwise to invest in mutually beneficial cooperation;

- to offer a longer contract;

- to increase volume of orders and complexity gradually, thus giving to the supplier an opportunity gradually to adapt their own technologies for more complex work.

Buyers often see themselves in an awkward position when they need the supplier rather than he is necessary for supplier. Small customer can consider possibilities more to connect his business with monopolistic enterprise, thus increasing their dependence (Jablanovic 2013; Willington, Ning 2014). This works in situations where the supplier has a monopolistic position in several business areas, but not in all. Such measures can increase the available negotiating power. Of course, it is necessary to avoid situations where only one supplier can provide a full package of services. Therefore it is important to divide the desired service into the parts, and giving more freedom of choice from several suppliers, without a transfer of negotiating powers for a single supplier. Or vice versa, the strategic move of the negotiations may include an opportunity to offer supplier to sell more if he would make a better offer.

\section{Supplier's reputation}

Some monopolistic suppliers strongly maintain their available position in the market and react harshly enough if they are accused of exploiting the situation for their own benefit (Mirman et al. 2014; Braido, Shalders 2015; Sarafopoulos 2015). The antitrust legislation is in US, Europe, Australia, Lithuania, which intends to regulate markets and prevent the abuse of a dominant market position. For example, in the United States works the Sherman Act, which not intends to prevent a dominant position of particular company in a particular industry, but it aims to prevent artificial price increases both in supply and trade. Frequently negotiators examine the following issues, analyzing the market situation (Rogers 2013): 
Peleckis, K.; Peleckiene, V.; Peleckis, K. 2017. International business negotiations: search of the balance and the equilibrium of negotiating powers, under distorting market conditions of competition (monopsony, oligopsony and monopoly cases)

- Is there evidence that the supplier or suppliers act inappropriately?

- Is on the market balance of different bargaining power?

- Does supplier use its privileged position?

- Is it possible to form an alliance with another group of buyers and act collectively?

Separation of business and private interests

Business relationship has a number of different aspects. Business relationships can be expressed in the following sections: business, personal and contractual dimensions (Table 1).

Table 1. Sections of business relations (Source: Mumuni et al. 2016; Rogers 2013)

\begin{tabular}{l|l|l}
\hline \multicolumn{2}{c}{ Business relations dimensions } \\
\hline \multicolumn{1}{c|}{ Business section } & \multicolumn{1}{c}{ Personal section } & \multicolumn{1}{c}{ Contractual section } \\
\hline Bilateral risks and opportunities & Influence models. & Agreement \\
Sizes of participants Matching goals & Number of interested parties & Specification \\
Balance of power & Similar values & Agreement on the service level. \\
Supply chain. & Degree of confidence & sanctions \\
Incentives & Personal sympathy & Operational Mode \\
\hline
\end{tabular}

Buyers often focus on aspects of the business, and sellers often focus on individual aspects, may influence business through specific individuals. This includes identification of key decision-makers, the analysis of their role, opportunities and exposure assessment, the relevant possibilities in addition to decision-makers and other relevant processes. There are a number of important aspects which should be evaluated (Rogers 2013):

-Does supplier's management structure is well-known?

-Do we have a relationship with the decision-makers?

- Do you know people who have contact with the supplier, and if not, with whom is a need to become familiar?

- What information should we provide?

The answers to these questions lead to a better knowledge of supplier, and the current situation of the business entity.

\section{Additional criteria for negotiations}

The supplier may heighten the price, if they know that the buyer of goods or services or customer will not be able to get them anywhere else. Suppliers often apply for customer groups better prices than for individual buyers. Of course, supplier may present proposal criteria, which are non-price related. Not only the price is negotiable criteria, there are other criteria which also contribute to the final result (Table 2). Often, purchasing managers are only the third or fourth level employees in organization. Thus, it is possible to influence by acting the other participants, occupying senior positions in the organization (Mendoza 2016). In order to influence must be included and the other participants which are related with the project. Opportunities arise in case, when the buyer cooperates with the representatives of his organization or supplier's organization, which have a similar approach to potential cooperation opportunities. Persons who prepare the specifications of contracts generally have a very significant impact on the freedom of choice and conclusion of deals.

Table 2. Additional criteria for negotiations (Source: developed by the authors according Shin 2017; Rogers 2013)

\begin{tabular}{l|l|l}
\hline \multicolumn{2}{c}{ Additional criteria for negotiations } \\
\hline $\begin{array}{l}\text { Discount for turnover. } \\
\text { Price stability. }\end{array}$ & Excess return of goods. & \multicolumn{1}{c}{ Advertising support. } \\
Price variation formula. & Onstallation fees. & Priority under lack of goods. \\
Package price. \\
Payment terms. & The instructions, drawings and plans. & Wider range of guarantees. \\
Payment currency. & Training and support services. & Special storage. \\
Payment deferral. & Safety and health issues. & Contract terms. \\
Shipping rates. & Packaging. & Access to modifications/ additions. \\
Delivery deadlines. & Packages returned. & Lonfidentiality. \\
Delivery places. & Insurance. & Resources for common projects. \\
Delivery frequency. & Specifications. & Research. \\
Urgent cases. & Samples for testing. & Special equipment provision. \\
Maintenance contracts. & Translations. & \\
Prices of spare parts. & Guarantees. & \\
\hline
\end{tabular}



negotiating powers, under distorting market conditions of competition (monopsony, oligopsony and monopoly cases)

There is a need to examine the need for each parameter in the specifications, as this can significantly tie to a particular supplier. Also suppliers have experience in other markets, so it is possible to cooperate in order to get into another market. In a monopoly situation in companies involved in such cases, when a company does not buying from a particular supplier can't get product or service. It is therefore likely that the company may begin to provide product or service for themselves and for other users. However, this case is hardly possible, as there may be too high input costs for entrance into the market.

There are several methods that may be useful depending on sales conditions, which are more tactical decisions than strategic. That may force a monopolist or a cartel to increase their flexibility. If we have a regular need to purchase non-perishable products, we can buy quantities, which exceed quantities we do not need in the current moment. Later on we can discontinue the contracts suddenly or significantly reduce them. Such action can force the supplier to worry and compel him to start to re-negotiate. But exceeded volume of purchases will win time for negotiations. You can buy a larger amount for a longer period, such as six months, it could become a sufficiently large amount to pay the supplier's attention, and this could also help to obtain better conditions. However should be evaluated and storage costs. If we make reservation for supplier of more or less at the end of the financial year, it could lead to his interest in. Because regular quantities ordered are likely to have been designed. However, it is important to assess how it will respond in the long run.

If product demand is expected in the long term, for this purpose can be concluded long-term contract. It is useful to supplier for safeguarding a regular income, although small. Therefore, in the contract could be envisaged (Rogers 2013; Willington, Ning 2014):

- delivery period must be financially weighed, that in the future we could receive benefits from this;

- to influence the price (of course the supplier can raise it, but you need to minimize the changes). The price can be tethered to a particular index, but you need to select them carefully, especially ones that are constantly rising;

- to foresee cases of price decreases;

- the limits of price increases over a specific time period;

- price increase generation within a specific period of time.

In some cases it is possible to form a consortium of buyers with similar needs, providing them the opportunities to buy on behalf of all consortium participants. This can provide greater bargaining power. How long does it take to create a dominant position in the market? For months or years. Thus before any impact on the market it is need to pay attention how enterprise project managers will respond to that. Spectrum of most purchases include horizon of several weeks, but it requires a long period in order to reset the balance of market power. Fact that the prices are very similar may be the result of intense competition, not the cartel. Symptoms of the price fixing agreements are as follows (Braido, Shalders 2015; Rogers 2013; Willington, Ning 2014):

- fixed price is available only in certain areas or working only with specific customers;

- prices of separate suppliers goes up at similar levels and at the same time, while their explanations for the rise in prices are similar;

- changes in prices of individual suppliers are similar at that time when the price determining factors did not change;

- discount system changes are very slight;

- the first offer is usually provided by one of the leading company and the other company provides as subsequently later.

Alternative of price cartel - companies share the territories or customers. In this case, may be selected customers in the relevant areas. Or the consensus is made on which undertaking will win a particular contract. Symptoms of such agreements are (Sarafopoulos 2015; Rogers 2013; Willington, Ning 2014):

- suppliers, which compete in one territory, refuses to supply in another area, thus encouraging to buy from another supplier (in no specific reason);

- suppliers who offer different prices in different areas as well show their competitiveness, which is not explained by differences in the markets;

- assurance of supplier that he will win and that the other participant will not participate or will not be competitive (such assurance is possible only with a contacts and potential agreement with the other competing participants).

Market division may be in places, where a few dominant suppliers, and buyers are operating in a fragmented and uncoordinated way. Often, suppliers claim that in some areas they are less competitive due to geography, logistics or other market characteristics. There may be agreements, when suppliers submit proposals, but provide by common contractor agreements, knowing the lowest bidding threshold, the system of discounts or price levels. More the buyer is predictable, the easier it is for suppliers to manipulate in determining who will win (Braido, Shalders 2015; Sarafopoulos 2015; Rogers 2013; Willington, Ning 2014):

- supplier chooses not to compete in order that another supplier would win; 
Peleckis, K.; Peleckiene, V.; Peleckis, K. 2017. International business negotiations: search of the balance and the equilibrium of negotiating powers, under distorting market conditions of competition (monopsony, oligopsony and monopoly cases)

- supplier offers are uncompetitive or does not meet specifications;

- suppliers submit proposals, but take place in the rotation according which it is supplier's turn to win the contract.

The buyers who concerned that they can become the victims of unfair competition is essential to follow circumstances, which are not typical in competitive situations. This may include following products, services or projects (Braido, Shalders 2015; Sarafopoulos 2015; Rogers 2013; Willington, Ning 2014):

- proposals are provided less acceptable than usual (which indicates that there is no tendency toward an agreement);

- proposals is completely different from the company's available options;

- the same supplier always provide the lowest price (over a long period of time accordingly);

- one company is always in a non-competitive market compared to other markets (and this can not be explained by market factors and logistics);

- after new supplier appearance in the market, fast and significant collective behavior starts;

- one company is always in a non-competitive market compared to other markets (and this can not be explained by market factors and logistics);

- whenever new supplier occurs, in the market starts fast and significant collective behavior.

\section{Conclusions}

1. In this article, we examined aspects of competition market distortion in cases of monopsony, oligopsony and monopolies, which are significant in development and implementation of bargaining power in international business. One of the reasons for the lack of competitive pressures in the market, is that the number of suppliers is not sufficient to create a free and open competition, such as in the monopoly case. Therefore, distortion of the market we can call where there is no free and open competition. Free competition means that market participants are competing with each other rather than cooperate with each other, supported by cartel relationship. Open competition means that the barriers to market entry are low enough and in that event profits of existing players are not too large, otherwise would come new suppliers, who would try to sell their goods or services with a smaller profit, on the whole it would be useful to customers, thereby ensure their sales. The buyer's power is concerned with how the buyers or users can influence the transaction terms with suppliers. Power is divided into two: monopsonistic power and bargaining power. The buyer has the monopsonistic power if he can reduce the price so that it would be significantly lower than the level of competition in the market between suppliers. Negotiating power depends on negotiating strength which the buyer shows during communication with suppliers. Lower price is derived from the monopsonistic power nor through negotiating power. Negotiating power is used only where the supplier has market power and is intended to offset it. The consequences of each buyer's power usage are very different. Monopsonistic and oligopsonic power reduce sales volumes and productivity in supply market, which ultimately negatively affects the consumer market. In terms of negotiating power held by buyers, it is more of a compensatory nature, ultimately increases the volume of production in suppliers market and improves consumer conditions in the consumer market.

2. There were analyzed measures, which help in situations of distorted competition market to reduce the negative impact on the balance of powers in international business negotiations. It can be identified some of the most important elements determining the balance of negotiating power: market structure, market concentration, competition. Judging situations of distorted competition opens up opportunities for international business, as presence of other market participants can provide additional alternatives in reducing the negative impact of competition distortions for balance of negotiating powers of the negotiating sides. When the number of buyers and sellers is small, the negotiations may be due to possible excess profits between the buyer and the seller, according to their capabilities. Excess profit distribution depends on the relative in negotiating power. Excess profit is a purpose for the buyer and seller and this encourages them to agree not to seek other alternatives. The a more efficient is bargaining of the buyer, thus more possible alternatives he has, the fewer alternatives has the seller, so the greater excess part of the profit will get the buyer. The buyer transaction profits depend on his ability and willingness to look for alternative suppliers. Similarly, the seller's transaction profit depends on the ability and willingness to look for other buyers. Development and implementation of effective international business strategies for negotiation, setting the power balance situation of negotiating countries' is important in order to make effective use of the potential of business negotiations - negotiation power.

3. Search for new suppliers can help to expand the availability of alternatives, thus increasing buyer's negotiating power. Also in attaining to have more alternatives, requires to expand the existing market boundaries. This can be done by examining similar or related markets, which can become a potential supplier's market. Sometimes for participants of other markets it is quite difficult to switch working in other market.

4. Therefore, finding a potential partner, who is supplying cheaper goods or services from other markets, is possible to anticipate possible negotiating proposals, which would facilitate determination of future potential partner work together in a new market: the sharing of experiences, for example posting project managers, or transferring part 
Peleckis, K.; Peleckiene, V.; Peleckis, K. 2017. International business negotiations: search of the balance and the equilibrium of negotiating powers, under distorting market conditions of competition (monopsony, oligopsony and monopoly cases)

of technologies through joint meetings; to subsidize some of the costs of entry, or buy the appropriate measures, or otherwise to invest in mutually beneficial cooperation; offer a longer contract; increase volume of orders and complexity gradually, thus giving to supplier the opportunity to adapt gradually their own technologies for more complex work.

5. Customers often see themselves in uncomfortable position when they need a supplier more than a supplier requires him. It can be considered the opportunity for better connection of your business with monopolistic enterprise, thus increasing their dependence. This affects when supplier has monopoly position in several business areas, but not in all. Such action can increase the available negotiating power. Of course, you should avoid situations where only one supplier can provide a full package of services, so it is important to split into parts the desired service as giving yourself more freedom of choice from several suppliers, without transfer of negotiating powers both for a single supplier. Or, conversely, negotiating strategy may be: to offer the supplier an opportunity to sell more if he would make a better offer.

\section{References}

Alavoine, C.; Estieu, C. 2015. You can't always Get what you Want: Strategic Issues in Negotiation Part 2, Procedia - Social and Behavioral Sciences 207: 335-343. https://doi.org/10.1016/j.sbspro.2015.10.103

Antaki, C.; Kent, A. 2015. Offering alternatives as a way of issuing directives to children: putting the worse option last, Journal of Pragmatics 78: 25-38. https://doi.org/10.1016/j.pragma.2015.01.004

Barr, T.; Roy, U. 2008. The effect of labor market monopsony on economic growth, Journal of Macroeconomics 30(4): 14461467. https://doi.org/10.1016/j.jmacro.2008.05.001

Bonanno, A.; Lopez, R. A. 2012. Wal-Mart's monopsony power in metro and non-metro labor markets, Regional Science and Urban Economics 42(4): 569-579. https://doi.org/10.1016/j.regsciurbeco.2012.02.003

Braido, L. H. B.; Shalders, F. L. 2015. Monopoly rents in contestable markets, Economics Letters 130: 89-92. https://doi.org/10.1016/j.econlet.2015.03.008

Brennan, T. J. 2011. Energy efficiency and renewables policies: promoting efficiency or facilitating monopsony?, Energy Policy 39(7): 3954-3965. https://doi.org/10.1016/j.enpol.2010.10.004

Brett, J.; Thompson, L. 2016. Negotiation, Organizational Behavior and Human Decision Processes 136: 68-79. https://doi.org/10.1016/j.obhdp.2016.06.003

Danziger, L. 2010. Endogenous monopsony and the perverse effect of the minimum wage in small firms, Labour Economics 17(1): 224-229. https://doi.org/10.1016/j.labeco.2009.07.006

Dassiou, X.; Glycopantis, D. 2008. Price discrimination through transactions bundling: the case of monopsony, Journal of Mathematical Economics 44(7-8): 672-681. https://doi.org/10.1016/j.jmateco.2006.11.003

Dinkevych, E.; Wilken, R.; Aykac, T.; Jacob, F.; Prime, N. 2016. Can outnumbered negotiators succeed? The case of intercultural business negotiations, International Business Review [online], $[15$ December 2016] Available from Internet: https://doi.org/10.1016/j.ibusrev.2016.12.001

Dunne, T. C.; Aaron, J. R.; McDowell, W. C.; Urban, D. J.; Geho, P. R. 2016. The impact of leadership on small business innovativeness, Journal of Business Research 69(11): 4876-4881. https://doi.org/10.1016/j.jbusres.2016.04.046

Ghavami, S. M.; Taleai, M.; Arentze, T. 2016. Socially rational agents in spatial land use planning: a heuristic proposal based negotiation mechanism, computers, Environment and Urban Systems 60: 67-78. https://doi.org/10.1016/j.compenvurbsys.2016.08.004

Jablanovic, V. D. 2013. The chaotic price growth model of the agricultural monopoly and new information and communication technology, Procedia Technology 8: 130-133. https://doi.org/10.1016/j.protcy.2013.11.018

Jäger, A.; Loschelder, D. D.; Friese, M. 2017. Using self-regulation to overcome the detrimental effects of anger in negotiations, Journal of Economic Psychology 58: 31-43. https://doi.org/10.1016/j.joep.2016.09.003

Khakhar, P.; Rammal, H. G. 2013. Culture and business networks: international business negotiations with Arab managers, International Business Review 22(3): 578-590. https://doi.org/10.1016/j.ibusrev.2012.08.002

Kiryluk-Dryjska, E. 2016. Negotiation analysis using the theory of moves - theoretical background and a case study, Journal of Policy Modeling 38(1) 44-53. https://doi.org/10.1016/j.jpolmod.2015.10.002

Kováč, E.; Žigić, K. 2016. Persistence of monopoly, innovation, and R\&amp; D spillovers, Research in Economics 70(4): 714734. https://doi.org/10.1016/j.rie.2016.07.006

Lai, L. W. C.; Chau, K. W.; Lorne, F. T. 2016. The rise and fall of the sand monopoly in colonial Hong Kong, Ecological Economics 128: 106-116. https://doi.org/10.1016/j.ecolecon.2016.04.021

Matsudaira, J. D. 2014. Monopsony in health labor markets, in Encyclopedia of health economics. A. J. Culyer (Ed.). San Diego: Elsevier, 325-333. https://doi.org/10.1016/B978-0-12-375678-7.01109-3

Matsumoto, A.; Szidarovszky, F. 2015. Learning monopolies with delayed feedback on price expectations, Communications in Nonlinear Science and Numerical Simulation 28(1-3): 151-165. https://doi.org/10.1016/j.cnsns.2015.04.011

Melnikas, B.; Smaliukiené, R. 2007. Consumer vulnerability in pharmaceutical market: case of Baltic countries, Journal of Business Economics and Management 8(1): 51-62.

Mendoza, D. K. O. 2016. Antitrust in the new economy case Google Inc. against economic competition on web, Mexican Law Review 8(2): 1-29. https://doi.org/10.1016/j.mexlaw.2016.07.001 
Peleckis, K.; Peleckiené, V.; Peleckis, K. 2017. International business negotiations: search of the balance and the equilibrium of negotiating powers, under distorting market conditions of competition (monopsony, oligopsony and monopoly cases)

Mirman, L. J.; Salgueiro, E. M.; Santugini, M. 2014. Noisy signaling in monopoly, International Review of Economics \& Finance 29: 504-511. https://doi.org/10.1016/j.iref.2013.07.009

Moosmayer, D. C.; Chong, A. Y.; Liu, M. J.; Schuppar, B. 2013. A neural network approach to predicting price negotiation outcomes in business-to-business contexts, Expert Systems with Applications 40(8): 3028-3035. https://doi.org/10.1016/j.eswa.2012.12.018

Mumuni, A. G.; Luqmani, M.; Quraeshi, Z. A. 2017. Telecom market liberalization and service performance outcomes of an incumbent monopoly, International Business Review 26(2): 214-224. https://doi.org/10.1016/j.ibusrev.2016.06.008

OECD. 2008. Policy roundtables: monopsony and buyer power. Competition Policy and Environment. 328 p.

Peleckis, K. 2016. International business negotiation strategies based on bargaining power assessment: the case of attracting investments, Journal of Business Economics and Management 17(6): 882-900. https://doi.org/10.3846/16111699.2016.1233511

Peleckis, K.; Peleckienè, V.; Peleckis, K.; Polajeva T. 2016. Towards sustainable entrepreneurship: role of nonverbal communication in business negotiations, The International Journal Entrepreneurship and Sustainability Issues 4(2): 228239. https://doi.org/10.9770/jesi.2016.4.2(10)

Petriwskyj, A.; Gibson, A.; Webby, G. 2015. Staff members' negotiation of power in client engagement: analysis of practice within an Australian aged care service, Journal of Aging Studies 33: 37-46. https://doi.org/10.1016/j.jaging.2015.02.011

Przybyła-Kasperek, M.; Wakulicz-Deja, A. 2016. The strength of coalition in a dispersed decision support system with negotiations, European Journal of Operational Research 252(3): 947-968. https://doi.org/10.1016/j.ejor.2016.02.008

Rogers, P. 2013. Dealing with monopolistic and distorted supply markets, Leading global excellence in procurement and supply. FCIPS of PMMS consulting group. Easton House. 20 p.

Rufo, M. J.; Martín, J.; Pérez, C. J. 2016. A Bayesian negotiation model for quality and price in a multi-consumer context, Reliability Engineering \& System Safety 147: 132-141. https://doi.org/10.1016/j.ress.2015.11.002

Sarafopoulos, G. 2015. Complexity in a monopoly market with a general demand and quadratic cost function, Procedia Economics and Finance 19: 122-128. https://doi.org/10.1016/S2212-5671(15)00014-3

Schaerer, M.; Loschelder, D. D.; Swaab, R. I. 2016. Bargaining zone distortion in negotiations: the elusive power of multiple alternatives, Organizational Behavior and Human Decision Processes 137: 156-171. https://doi.org/10.1016/j.obhdp.2016.09.001

Shin, E. 2017. Monopoly pricing and diffusion of social network goods, Games and Economic Behavior 102: 162-178. https://doi.org/10.1016/j.geb.2016.12.004

Strobl, E.; Walsh, F. 2007. Dealing with monopsony power: employment subsidies vs. minimum wages, Economics Letters 94(1): 83-89. https://doi.org/10.1016/j.econlet.2006.08.005

Weiss, A. P. C. 2017. Negotiation: how to be effective, The Journal of Hand Surgery 42(1): 53-56. https://doi.org/10.1016/j.jhsa.2016.10.009

Wilken, R.; Jacob, F.; Prime, N. 2013. The ambiguous role of cultural moderators in intercultural business negotiations, International Business Review 22(4): 736-753. https://doi.org/10.1016/j.ibusrev.2012.12.001

Willington, M.; Ning, J. L. 2014. Regulating a monopoly with universal service obligations: the role of flexible tariff schemes, Telecommunications Policy 38(1): 32-48. https://doi.org/10.1016/j.telpol.2013.04.005 